\title{
Financial Considerations Associated With a Fourth Year of Residency Training in Family Medicine: Findings From the Length of Training Pilot Study
}

Patricia A. Carney, PhD, MS; Annie Ericson, MA; Colleen M. Conry, MD; James C. Martin, MD;

Perry A. Pugno, MD, MPH, CPE; Deborah S. Clements, MD; Samuel Jones, MD; M. Patrice Eiff, MD

BACKGROUND AND OBJECTIVES: The feasibility of funding an additional year of residency training is unknown, as are perspectives of residents regarding related financial considerations. We examined these issues in the Family Medicine Length of Training Pilot.

METHODS: Between 2013 and 2019, we collected data on matched 3-year and 4-year programs using annual surveys, focus groups, and in-person and telephone interviews. We analyzed survey quantitative data using descriptive statistics, independent samples t test, Fisher's Exact Test and $\chi^{2}$. Qualitative analyses involved identifying emergent themes, defining them and presenting exemplars.

RESULTS: Postgraduate year (PGY)-4 residents in 4-year programs were more likely to moonlight to supplement their resident salaries compared to PGY-3 residents in three-year programs $(41.6 \%$ vs $23.0 \%$; $P=.002)$, though their student debt load was similar. We found no differences in enrollment in loan repayment programs or pretax income. Programs' descriptions of financing a fourth year as reported by the program director were limited and budget numbers could not be obtained. However, programs that required a fourth year typically reported extensive planning to determine how to fund the additional year. Programs with an optional fourth year were budget neutral because few residents chose to undertake an additional year of training. Resources needed for a required fourth year included resident salaries for the fourth year, one additional faculty, and one staff member to assist with more complex scheduling. Residents' concerns about financial issues varied widely.

CONCLUSIONS: Adding a fourth year of training was financially feasible but details are local and programs could not be compared directly. For programs that had a required rather than optional fourth year much more financial planning was needed.

(Fam Med. 2021;53(4):256-66.)

doi: $10.22454 /$ FamMed.2021.406778

$\mathbf{T}$ he optimal length of training in family medicine has been hotly debated in the United States. for more than a decade. ${ }^{1-8}$ Proponents of longer training suggest an additional year should be added to address a broad scope of practice within the context of clinical and educational work hour requirements, ${ }^{9-11}$ lack of adequate preparation in medical school, ${ }^{12-14}$ and skills needed to perform in complex health care systems. ${ }^{15,16}$ Some have advocated for a 2-year training model similar to Canada. The decision is further complicated by challenges in how residency training is financed in the United States. Most US family medicine residency programs rely heavily on federal graduate medical education (GME) funding to support their residents and faculty salaries as well as program operations. ${ }^{17}$ However, that funding has been largely fixed since the introduction of caps on resident positions in 1997; thus, sponsoring institutions may be reluctant to allow residencies to add additional positions to their program without this traditional source of salary support. Federal funding formulas for direct medical education expenses (DME) currently provide only $50 \%$ funding for family medicine residents in a fourth year of training. However, if the discipline changed to 4 years of training, the Centers for Medicare and Medicaid Service would automatically pay for all 4 years.

From Oregon Health \& Science University, Portland, OR (Drs Carney and Eiff, and Ms Ericson); University of Colorado, Denver, CO (Dr Conry); Long School of Medicine, University of Texas Health Science Center at San Antonio (Dr Martin); Department of Family and Community Medicine, University of Kansas, Lawrence, KS (Dr Pugno); Department of Family and Community Medicine, Northwestern University Feinberg School of Medicine, Chicago, IL (Dr Clements); and Virginia Commonwealth University -Fairfax Family Medicine Residency, Fairfax, VA (Dr Jones). 
Another consideration includes the decisions medical students make regarding an acceptable length of residency training given their debt load. In 2016, the Association of American Medical Colleges Graduation and Tuition and Student Fees survey indicated the average debt load for graduating medical students was $\$ 190,000 .{ }^{18}$ Research has shown that stress related to personal finances affects physical health and well-being among physician trainees. ${ }^{19} \mathrm{In}$ fact, a recent study of the impact of debt load found high debt was correlated with callousness, stress, suicidal thoughts, failing medical licensing exams, and leaving or being dismissed from medical school. ${ }^{20}$ It is therefore important to understand whether residents view the opportunity cost of a fourth year of training as worth a year of lost practice income.

A well-established challenge in determining of how residency training is financed is the reported lack of transparency and accountability that exists in this regard. ${ }^{21,22}$ One survey study that had a $72 \%$ response rate from residency program directors reported that $59.3 \%$ of directors had attempted to discover this information and fewer than half were successful. ${ }^{21}$ Another challenge with attempting to ascertain this information in detail is that there is no way to validate that it is correct.

The Length of Training Pilot (LoTP) Study in family medicine was designed to address eight core research questions, one of which includes: "Is adding a fourth year of training financially feasible for residency programs?" As reported in other studies, we were unable to obtain specific budget data from all LoTP programs that would have allowed us to conduct a comparative quantitative financial analysis to address this research question. Thus, this paper reports on financial considerations of an additional year of training from the perspectives of residents and residency directors.

\section{Methods}

Length of Training Pilot

The LOTP, which runs from 2013 to 2022 , is a mixed-methods prospective case-control pilot study designed to assess how the length of family medicine residency training affects both learner and program outcomes, such as scope of practice, preparedness for independent practice and clinical knowledge. ${ }^{23}$ Residency programs that had already transitioned to 4 years of training or that were planning to do so applied for the pilot in 2012 and, after approval, were matched to 3-year programs (3YR) based on region, size, and clinical training setting.

The LoTP includes a total of 17 residency programs that meet specific eligibility requirements, including being in good standing with the Accreditation Council for Graduate Medical Education (ACGME), and participating in all required evaluation activities. Seven 3YR civilian programs, six 4YR civilian programs, and four Navy programs applied for and were enrolled in the study. The Navy programs were excluded from these analyses because the costs associated with their programs are vastly different from civilian programs. Because of the large size of one $4 \mathrm{YR}$ program, two 3YR programs were matched to it to ensure equivalent numbers of residents in $3 \mathrm{YR}$ and $4 \mathrm{YR}$ groups. The 4YR programs included two university-based programs and four communitybased, medical school-affiliated programs. They ranged in size from six to 22 residents per year. Four of the six 4 YR programs required 4 years of training for all graduates, while two offered an optional fourth year of training where residents knew at the time of entry to the program that completing a fourth year was possible. Three-year programs included two that were university-based, four that were community-based, medical school-affiliated, and one communitybased, nonaffiliated, and ranged in size from six to 11 residents per year.

Evaluation of the pilot is overseen by a team of educational researchers in the Department of Family Medicine at Oregon Health \& Science University (OHSU). All LoTP programs obtained Institutional Review Board (IRB) approval. OHSU's Institutional Review board granted the evaluation team an educational exemption to obtain data from the study sites (IRB\# 9770).

\section{Instrument Design and Data Collection}

Residents and Graduates Data Collection. Quantitative resident financial data, collected from a resident survey administered annually between 2013-2018, included student loan debt, enrollment in loan repayment programs, moonlighting status and reasons to moonlight. We also asked 4YR programs to provide resident salaries according to program year and $66.7 \%$ did so. Graduate financial data, collected from a graduate survey administered annually 1 year after training was completed, included pretax income.

We derived resident perspectives on financial considerations from inperson focus groups during site visits and group telephone interviews. The financial question asked of $4 \mathrm{YR}$ program residents was: "How have you thought about financial considerations of a fourth year of training?" and of 3YR program residents: "How did financial considerations impact your decision to pursue a $3 \mathrm{YR}$ versus 4YR residency?" The questions posed to residents of $4 \mathrm{YR}$ and $3 \mathrm{YR}$ programs were slightly different to reflect the fact that residents in $4 \mathrm{YR}$ programs had already made their decision to pursue an additional year of training, so our interview prompts to elicit their perspective on financial considerations reflected this. In $4 \mathrm{YR}$ programs, a total of 47 residents participated in focus groups during site visits (2013-2014) and 22 residents participated in group telephone interviews in 2019. In 3YR programs, a total of 25 residents participated in group telephone interviews during virtual site visits (2014) and 28 residents participated in group telephone interviews in 2019. 
Program Data Collection. We collected data on financial considerations of a fourth year of training from the program perspective during in-person meetings with $4 \mathrm{YR}$ program directors during site visits $(n=6)$ and during annual telephone follow-up calls, during which three independent recorders collected field notes. Questions asked of the 4YR program directors included (1) "What was your approach to financing the fourth year of training?"; (2) "What approaches did you take to negotiate for additional resources?"; (3) "What resources did you need?"; and (4) "What financial advice would you give to other residency directors who are considering offering 4 years of training?"

\section{Data Analyses}

We used responses from PGY-3 residents in 3YR programs or PGY-4 residents in 4YR programs for demographics, student loan debt and loan repayment program enrollment. The graduate survey data were taken 1 year postgraduation for residents of both 3YR and 4YR programs. We excluded residents who trained in
4YR programs but who graduated after just 3 years of training because the study was designed to evaluate length of training. All of these were from optional 4YR programs. We analyzed quantitative data using descriptive statistics ( $\chi^{2}$ or Fisher's Exact test). All tests were two-sided with $\alpha$ levels set at 0.05 .

Three independent observers collected field notes (notes recorded by trained observers to capture responses to questions asked by the facilitator) during in-person or telephone group interviews or focus groups. These were compiled into single composite documents to ensure the study record was complete for each event. Two study team members (P.A.C. and A.E.) conducted qualitative analyses of the composite documents. They used open coding of relevant passages and phrases in composite reports and then compared codes during consensus meetings held between July 2019 and August 2019. We applied the consensus open codes to the composite reports, a process that was repeated until coding was complete which included combining, eliminating and refining codes using constant comparative analyses. ${ }^{24} \mathrm{We}$ achieved code saturation when no new codes were applied to the data, and saturated open codes were applied to the remaining composite reports. The analysis team then conducted axial coding ${ }^{25}$ and determined definitions for the selective $\operatorname{codes}^{24}$ in the form of themes and subthemes for each code category. We then selected exemplar statements from composite reports to illustrate these themes.

\section{Results}

\section{Participating Residents}

No statistical differences were found for age, gender, race/ethnicity, marital or parental status, student loan debt load, or enrollment in loan repayment or scholarship programs between the two study groups (Table 1 ), though females predominated in both study groups.

\section{Financial Considerations Among Residents}

We found that PGY-4 residents in 4YR programs were more likely to moonlight compared to PGY-3 residents in 3YR programs $(4 \mathrm{YR}=41.6 \%$

Table 1: Characteristics of Residents and Program Graduates Included in Analyses

\begin{tabular}{|c|c|c|c|}
\hline Characteristics & \multirow{2}{*}{$\begin{array}{l}\text { Year } 3 \\
\mathbf{n}^{\dagger}(\%)\end{array}$} & \multirow{2}{*}{$\begin{array}{l}\text { Year } 4 \\
n^{\dagger}(\%)\end{array}$} & \multirow{2}{*}{$P$ Value } \\
\hline Residents* & & & \\
\hline Mean age (standard deviation) & $\begin{array}{c}(\mathrm{n}=175) \\
32.3(3.8)\end{array}$ & $\begin{array}{c}(\mathrm{n}=106) \\
32.6(2.6)\end{array}$ & .67 \\
\hline $\begin{array}{l}\text { Gender identity } \\
\text { Male } \\
\text { Female }\end{array}$ & $\begin{array}{c}(\mathrm{n}=176) \\
67(38.1) \\
109(61.9)\end{array}$ & $\begin{array}{c}(\mathrm{n}=106) \\
44(41.5) \\
62(58.5)\end{array}$ & .57 \\
\hline $\begin{array}{l}\text { Race } \\
\text { White } \\
\text { Black } \\
\text { Asian or Pacific Islander } \\
\text { Other }\end{array}$ & $\begin{array}{c}(\mathrm{n}=172) \\
125(72.7) \\
9(5.2) \\
34(19.8) \\
8(4.7)\end{array}$ & $\begin{array}{c}(\mathrm{n}=105) \\
80(76.2) \\
2(1.9) \\
20(19.0) \\
5(4.8)\end{array}$ & .52 \\
\hline $\begin{array}{l}\text { Ethnicity } \\
\text { Hispanic } \\
\text { Non-Hispanic }\end{array}$ & $\begin{array}{c}(\mathrm{n}=173) \\
9(5.2) \\
164(94.8)\end{array}$ & $\begin{array}{c}(\mathrm{n}=105) \\
5(4.8) \\
100(95.2)\end{array}$ & .87 \\
\hline $\begin{array}{l}\text { Marital Status } \\
\text { Single } \\
\text { Married/partnered } \\
\text { Divorced } \\
\text { Widowed }\end{array}$ & $\begin{array}{c}(\mathrm{n}=176) \\
66(37.5) \\
109(61.9) \\
1(0.6) \\
0(0)\end{array}$ & $\begin{array}{l}(\mathrm{n}=106) \\
35(33.0) \\
69(65.1) \\
1(0.9) \\
1(0.9)\end{array}$ & .59 \\
\hline $\begin{array}{c}\text { Parental status } \\
\text { Has children }\end{array}$ & $\begin{array}{c}(\mathrm{n}=176) \\
60(34.1)\end{array}$ & $\begin{array}{c}(\mathrm{n}=106) \\
32(30.2)\end{array}$ & .50 \\
\hline
\end{tabular}


Table 1: Continued

\begin{tabular}{|c|c|c|c|}
\hline Characteristics & \multirow{2}{*}{$\begin{array}{l}\text { Year } 3 \\
\mathbf{n}^{\dagger}(\%)\end{array}$} & \multirow{2}{*}{$\begin{array}{l}\text { Year } 4 \\
\mathbf{n}^{\dagger}(\%)\end{array}$} & \multirow{2}{*}{$P$ Value } \\
\hline Residents* & & & \\
\hline $\begin{array}{l}\text { Attended medical school in the United States } \\
\text { Yes }\end{array}$ & $\begin{array}{c}(\mathrm{n}=176) \\
138(78.4)\end{array}$ & $\begin{array}{l}(\mathrm{n}=106) \\
93(87.7)\end{array}$ & $.06^{\dagger \dagger}$ \\
\hline $\begin{array}{l}\text { Student loan debt load } \\
\text { No student loans } \\
<\$ 25,000 \\
\$ 25,000-\$ 74,999 \\
\$ 75,000-\$ 149,999 \\
\$ 150,000-\$ 249,999 \\
\$>250,000\end{array}$ & $\begin{array}{c}(\mathrm{n}=161) \\
17(10.6) \\
8(5.0) \\
11(6.8) \\
26(16.1) \\
35(21.7) \\
64(39.8)\end{array}$ & $\begin{aligned} &(\mathrm{n}=90) \\
& 16(17.8) \\
& 1(1.1) \\
& 6(6.7) \\
& 13(14.4) \\
& 24(26.7) \\
& 30(33.3)\end{aligned}$ & .38 \\
\hline $\begin{array}{l}\text { Enrolled in loan repayment or scholarship programs } \\
\text { Yes }\end{array}$ & $\begin{array}{l}(\mathrm{n}=161) \\
44(27.3)\end{array}$ & $\begin{array}{c}(\mathrm{n}=90) \\
35(38.9)\end{array}$ & $.07^{\dagger \dagger}$ \\
\hline $\begin{array}{l}\text { Moonlights to supplement resident salary } \\
\text { Yes }\end{array}$ & $\begin{array}{c}(\mathrm{n}=161) \\
37(23.0)\end{array}$ & $\begin{array}{c}(\mathrm{n}=89) \\
37(41.6)\end{array}$ & .002 \\
\hline Reason for moonlighting & $(\mathrm{n}=37)$ & $(\mathrm{n}=36)$ & .34 \\
\hline Gain experience & $33(89.2)$ & $32(88.9)$ & \\
\hline Extra income & $31(83.8)$ & $24(66.7)$ & \\
\hline Help with living expenses & $23(62.2)$ & $18(50.0)$ & \\
\hline Pay off debt & $19(51.4)$ & $20(55.6)$ & \\
\hline Graduates & Year $3(n=209)$ & Year $4(n=109)$ & $P$ Value \\
\hline $\begin{array}{l}\text { Total pretax income, including bonuses, but excluding benefits of } \\
\text { graduates }\end{array}$ & $\mathrm{n}(\%)$ & $\mathrm{n}(\%)$ & .12 \\
\hline$\$ 0-\$ 65,000$ & $3(1.4)$ & $3(2.8)$ & \\
\hline$\$ 65,001-\$ 125,000$ & $25(12.0)$ & $8(7.3)$ & \\
\hline$\$ 125,001-\$ 150,000$ & $23(11.0)$ & $12(11.0)$ & \\
\hline$\$ 150,001-\$ 175,000$ & $38(18.2)$ & $16(14.7)$ & \\
\hline$\$ 175,001-\$ 200,000$ & $37(17.7)$ & $35(32.1)$ & \\
\hline$\$ 200,001-\$ 250,000$ & $53(25.4)$ & $25(22.9)$ & \\
\hline$\$ 250,001-\$ 300,000$ & $22(10.5)$ & $6(5.5)$ & \\
\hline$>\$ 300,000$ & $8(3.8)$ & $4(3.7)$ & \\
\hline Certificates for Added Qualifications** & $\begin{array}{c}n(\%) \\
(n=213)\end{array}$ & $\begin{array}{c}n(\%) \\
(n=112)\end{array}$ & $\boldsymbol{P}$ Value $^{\dagger+}$ \\
\hline Geriatrics & $2(0.9)$ & $1(0.9)$ & .46 \\
\hline Sports medicine & $6(2.8)$ & $5(4.5)$ & \\
\hline Hospice/palliative care & $1(0.5)$ & $0(0)$ & \\
\hline Sleep medicine & $1(0.5)$ & $0(0)$ & \\
\hline
\end{tabular}

* Data collected using resident survey for PGY3 (in 3-year programs) or PGY-4 residents (in 4-year programs).

$\uparrow$ Numbers vary due to missingness.

** Neither type of program had certificates for added qualification for adolescent medicine.

\# Fisher's exact test.

Assessed at 1 year postgraduation. 
vs $3 \mathrm{YR}=23 \% ; P=.002$ ), even though their student debt load was not different. The main reasons they reported for moonlighting included to gain experience $(3 \mathrm{YR}=89.2 \%$, $4 \mathrm{YR}=88.9 \%$ ) and to obtain extra income (3YR=83.8\%, 4YR=66.7\%), with about half reporting they moonlight to pay off debt (3YR=51.4\%, $4 \mathrm{YR}=55.6 \%$ ). None of these reasons were statistically significant between the two groups. Graduates also did not differ according to total pretax income or the percent who had certificates of added qualification (Table 1). Among residents in the 4YR programs, fourth-year salaries in 2013-2014 averaged $\$ 61,469$ ( $\mathrm{SD}=\$ 1,935$; range $\$ 51,078-\$ 62,737$ ) and increased to $\$ 67,324$ in 2019 2020 (SD $=\$ 8,827$; range $\$ 61,100$ $\$ 73,584$, data not shown).

Eight themes emerged based on the question, "How did financial aspects of 4 years of training affect your decision to choose a 4 YR residency?" These included lost income (due to delaying entry into independent clinical practice), higher income (fourth year of training as a bargaining chip to get a higher salary), nonmonetary paybacks of additional training (benefits of gaining additional skills, including procedures, and confidence), delay in loan repayment (viewed by some as positive because of deferral, and viewed by others as negative because the start of repayment is delayed), philosophical issues related to income (if income mattered, they would not have chosen family medicine), higher salary in fourth year of training (salary structure significantly higher in fourth year), family considerations (needs of family are affected by additional training, that was perceived as more important than financial considerations), and avoidance (trying not to think about lost income, Table 2).

Four themes emerged from residents in 3YR programs who responded to the question, "How did financial considerations impact your decision to pursue a 3-year versus 4-year residency?" These included delay in loan repayment (viewed as negative because the start of repayment is delayed); concerns about burnout (financial considerations trumped by concerns about fatigue and stress related to an additional year of training); fourth year is not needed (financial considerations less important than the perspective that a fourth year is just not necessary for independent clinical practice); not sure what a fourth year would add (financial considerations trumped by uncertainty about what a fourth year of training would add, Table 3).

Table 2: Four-Year Program Resident Perceptions on Financial Considerations Regarding an Additional Year of Training-Question Stem: "How have you thought about financial considerations of a fourth year of training?"

\begin{tabular}{|c|c|}
\hline Emergent Theme & Thematic Definition and Exemplars \\
\hline Lost income & $\begin{array}{l}\text { This theme referred to the loss of income from delaying entry into independent clinical practice } \\
\text { for an additional year. Some residents calculated this out, while others just commented that it } \\
\text { would occur (Sites } 4 \mathrm{~B}, 4 \mathrm{D}) \text {. } \\
\text { Exemplar: "It's a financially poor decision. I would give up } \$ 200,000 \text { of additional income if I } \\
\text { stayed and did a fourth year" (Site } 4 \mathrm{~B} \text { ). }\end{array}$ \\
\hline Higher income & $\begin{array}{l}\text { This theme referred to using the extra year of training as a bargaining chip to get a higher } \\
\text { salary (Site } 4 \mathrm{C}, 4 \mathrm{D}, 4 \mathrm{E}) \text { or that more experience with coding/billing as a result of the additional } \\
\text { year of training can result in an increased salary (Site } 4 \mathrm{D}) \text {. } \\
\text { Exemplar: "I am more skilled at negotiating and this will help with getting a higher starting } \\
\text { salary" (Site } 4 \mathrm{C} \text { ). } \\
\text { Exemplar: "Our program produces a lot of quality data for each of us so perhaps that will give } \\
\text { me leverage to get a higher salary since I can show the quality of care I provide" (Site } 4 \mathrm{E} \text { ). } \\
\text { Exemplar: "Some of our PCMH training and leadership skills may get us different kinds of } \\
\text { jobs" (Site } 4 \mathrm{E}) \text {. }\end{array}$ \\
\hline $\begin{array}{l}\text { Nonmonetary paybacks } \\
\text { of additional training }\end{array}$ & $\begin{array}{l}\text { This theme referred to other benefits of additional training, including getting additional skills } \\
\text { and gaining confidence (Site 4C, 4D), with some residents noting that duty hour restrictions } \\
\text { have reduced clinical skills attainment (Site 4D). Several residents thought the financial issues } \\
\text { associated with additional training is the wrong argument for not doing an additional year. } \\
\text { Exemplar: "The time I spend training gives me that much more skills" (Site 4C). } \\
\text { Exemplar: "You recoup those finances in the skills that you build" (Site 4C). } \\
\text { Exemplar: "... knowing that the reason I love family medicine is the huge scope-I want to do } \\
\text { procedures and peds-the only way to feel competent is with the extra training. It started as a } \\
\text { source of concern and now is a source of pride" (Site } 4 \mathrm{C}) \text {. } \\
\text { Exemplar: "A long-term investment carries a short-term price tag" (Site } 4 \mathrm{C} \text { ). }\end{array}$ \\
\hline
\end{tabular}


Table 2: Continued

\begin{tabular}{|c|c|}
\hline Emergent Theme & Thematic Definition and Exemplars \\
\hline Delay in loan repayment & $\begin{array}{l}\text { This theme referred to delays in loan repayments as being both positive because they can be } \\
\text { deferred (Site 4D) and negative because the start of paying them off is delayed (Sites } 4 \mathrm{~B} \text {, Site } \\
4 \mathrm{~F}) \text {. } \\
\text { Positive Exemplar: "Yes, you take a hit financially, but you can defer loans for another year." } \\
\text { (Site 4D) } \\
\text { Negative Exemplar: "You have to pay back your debt sometime and doing a fourth year puts } \\
\text { this off further" (Site } 4 \mathrm{~B}) \text {. } \\
\text { Negative Exemplar: "Academically it's great. It's all rainbows. But every month I get a } \\
\text { statement of how my debt is going up" (Site } 4 \mathrm{~F}) \text {. }\end{array}$ \\
\hline $\begin{array}{l}\text { Philosophical issues } \\
\text { related to income }\end{array}$ & $\begin{array}{l}\text { This theme referred to the idea that if income mattered to them, they would not have chosen } \\
\text { family medicine (Site } 4 \mathrm{~A} \text {, Site } 4 \mathrm{E} \text { ). Other comments indicated that the addition of another year } \\
\text { just does not make that much difference (Site } 4 \mathrm{E} \text { ), while others thought the additional year } \\
\text { would bring prestige to the discipline of family medicine ([FM] Site } 4 \mathrm{~A} \text { ). } \\
\text { Exemplar: "Financial considerations not a big deal-didn't go into FM for the money" (Site } 4 \mathrm{E} \text { ). } \\
\text { Exemplar: "A year's a year. This is a second career for me so deciding to put finances on hold... } \\
\text { it's an investment to something that is important" (Site } 4 \mathrm{E} \text { ). } \\
\text { Exemplar: "It will increase the prestige of family medicine if it creates more respect for the } \\
\text { specialty. If that comes out of this in the next } 15 \text { years then applications will spike" (Site } 4 \mathrm{~A}) \text {. } \\
\text { Exemplar: "Making the move to four years could lead to greater respect for FPs because we } \\
\text { will be better trained and more skilled and have expanded scope with less referrals (specialists } \\
\text { know we can manage a breadth of conditions without referring unnecessarily)" (Site } 4 \mathrm{~A}) \text {. }\end{array}$ \\
\hline $\begin{array}{l}\text { Higher salary in fourth } \\
\text { year of training }\end{array}$ & $\begin{array}{l}\text { This theme reflected changes in salary structure as being significantly higher in the fourth } \\
\text { year, which they were satisfied with (Sites } 4 \mathrm{~A}, 4 \mathrm{C} \text { ). } \\
\text { Exemplar: "We also are going to make more money in our fourth year than any of us thought. } \\
\text { They will pay us like fellows" (Site } 4 \mathrm{~A} \text { ). }\end{array}$ \\
\hline Family considerations & $\begin{array}{l}\text { This theme went beyond the individual aspects of the decision to undertake an additional year } \\
\text { of training and focused on family needs, such as parental issues, family-related income, and } \\
\text { location issues affected by additional training (Sites } 4 \mathrm{~A}, 4 \mathrm{~F} \text { ). } \\
\text { Exemplar: "Managing family issues, child-rearing decisions, dual income families are impacted } \\
\text { by length of training" (Sites } 4 \mathrm{~A}, 4 \mathrm{~F} \text { ). }\end{array}$ \\
\hline Avoidance & $\begin{array}{l}\text { This theme referred to trying not to think about any lost income related to additional training } \\
\text { (Sites 4A, 4E). } \\
\text { Exemplar: "I try not to think about it" (Site } 4 \mathrm{E}) \text {. } \\
\text { Exemplar: "I don't look at my bank account" (Site } 4 \mathrm{E}) \text {. }\end{array}$ \\
\hline
\end{tabular}

Abbreviation: PCMH, patient-centered medical home.

\section{Financial Considerations of $4 Y R$ Programs}

Programs' descriptions of financing a fourth year of training varied according to whether the extra year was required of all residents or was optional (Table 4). Programs that required a fourth year typically undertook extensive planning to determine how to fund the additional year of training. Some reduced their complement of residents to cover fourth-year residents' salaries. Some residencies initially reduced their complement and then increased it over time as the clinical productivity of fourth-year residents increased. One program contracted with another health system to establish a new continuity clinic site for residents to support the costs of the additional year of training. For programs with an optional fourth year of training, this change was essentially budget neutral because only a few residents chose to undertake the additional year of training.

The resources needed for programs with a required fourth year typically included resident salaries for the fourth year of training, one additional faculty full-time equivalent (FTE), and one additional staff member to assist with more complex scheduling. Resources needed by programs with an optional fourth year did not include adding faculty or staff because so few residents chose a fourth year. One program had costs associated with tuition for a master's degree in public health or a master's degree in business administration, but they negotiated with their sponsoring institution to allow residents 
to benefit from a substantial tuition reduction (Table 4).

Programs with a required fourth year typically used consultants (eg, Residency Program Solutions) to help determine whether a fourth year was financially feasible. One site received consultation on how to improve billing and coding to optimize net revenue per patient visit. These programs developed an accounting of what it would take to expand and then negotiated with their sponsoring institutions to execute the transition. The advice that residencies with a required fourth year would offer other program directors who are considering adding a fourth year of training included seeking outside partnerships, such as other health systems, and improving financial literacy regarding the costs of training. Advice from those who had an optional fourth year of training included maximizing internal funds that are easier to access and using program strengths to get local resources (Table 4).

\section{Discussion}

This study examined financial considerations associated with extending residency training in family medicine by an additional year. It includes the perspectives of residents who trained in required and optional 4YR programs as well as those in 3YR programs. It also includes the viewpoints of program directors in both optional and required 4YR programs. We learned that offering an optional fourth year of training had much less financial impact on the programs than offering a required fourth year. A required fourth year necessitated one additional faculty and one staff member that was not needed if a fourth year of training was optional because the programs could absorb the costs of having between a few to about $33 \%$ of their residents undertaking an additional year of training. This finding is important because the RC-FM requires one core faculty member for every six residents. ${ }^{26}$ Thus, depending on the size of the program, $4 \mathrm{YR}$ programs may either need to hire more than one core faculty member or grant core faculty designation to another existing faculty member to be compliant.

Our findings also revealed that program directors explored various options, including potential additional institutional GME funding, and potential new financial income based on clinical productivity and more accurate billing strategies. Often, clinical productivity in the fourth year of training was an important source of income to support resident salaries in that training year, an important finding. However, our study did not discern whether the increase in residency visits represents a shift from faculty visits, which may affect the bottom-line revenues. Neither did we fully explore the extent to which highly capitated environments may have affected these costs. The most recent National Data Report from the Residency Review Committee for Family Medicine shows that the mean number of patient visits for fourth-year residents during 20172018 was $839(\mathrm{SD}=235.9$, range 299-1,279; $\mathrm{n}=48$ residents), and the average for PGY-3 residents was 924 $(\mathrm{n}=4,057){ }^{27}$ The importance of clinical productivity as a revenue source rests in the planning phase for the additional fourth year. Programs considering a move to an additional year of training should assess their practice population to ensure they

Table 3: Three-Year Program Resident Perceptions on Financial Considerations Regarding an Additional Year of Training-Question Stem: "How did financial considerations impact your decision to pursue a 3-year versus 4-year residency?"

\begin{tabular}{|l|l|}
\hline \multicolumn{1}{|c|}{ Emergent Theme } & \multicolumn{1}{c|}{ Thematic Definition and Exemplars } \\
\hline Delay in loan repayment & $\begin{array}{l}\text { This theme referred to delays in loan repayments as being negative because the start of paying } \\
\text { them off is delayed. } \\
\text { Exemplar: "I wanted to get started as an attending and continue learning and paying back my } \\
\text { loan" (Site 3A). }\end{array}$ \\
\hline $\begin{array}{l}\text { Not a financial } \\
\text { decision-concerns about } \\
\text { burnout }\end{array}$ & $\begin{array}{l}\text { This theme referred to concerns about stress and fatigue from doing an additional year of } \\
\text { residency rather than the decision being driven by financial considerations. } \\
\text { Exemplar: "I felt I'd be fried within 3 years and ready to do something else" (Site 3B). } \\
\text { Exemplar: "I wanted to avoid the stress of another year of training as a resident" (Site 3D). }\end{array}$ \\
\hline $\begin{array}{l}\text { Not a financial } \\
\text { concern-Fourth year } \\
\text { not needed }\end{array}$ & $\begin{array}{l}\text { This theme referred to the additional year being unnecessary for independent clinical practice } \\
\text { rather than the decision being driven by financial considerations. } \\
\text { Exemplar: "Third-year residents are considered faculty and are more colleagues than learners. } \\
\text { They report an environment of 'supervised independence. They feel well prepared for } \\
\text { independent practice" (Site 3E). } \\
\text { Exemplar: "I think extended learning happens more on the job than in an additional year" } \\
\text { (Site 3F). }\end{array}$ \\
\hline $\begin{array}{l}\text { Not a financial } \\
\text { concern-not sure what } \\
\text { a fourth year would add }\end{array}$ & $\begin{array}{l}\text { This theme referred to a lack of understanding about what an additional year would add } \\
\text { rather than the decision being driven by financial considerations. } \\
\text { Exemplar: "Having done three years, not sure another year would help" (Site 3E). } \\
\text { Exemplar: "An additional year would be more fine tuning of things" (Site 3E). }\end{array}$ \\
\hline
\end{tabular}


Table 4: Program Considerations Regarding How to Finance the Fourth Year of Training

\begin{tabular}{|c|c|c|}
\hline $\begin{array}{l}\text { Type of 4-Year } \\
\text { Program }\end{array}$ & Interview Questions & Findings \\
\hline \multirow{4}{*}{$\begin{array}{l}4 \text { years of } \\
\text { training } \\
\text { required for all } \\
\text { graduates }\end{array}$} & $\begin{array}{l}\text { What was your approach } \\
\text { to financing the fourth } \\
\text { year of training? }\end{array}$ & $\begin{array}{l}\text { Revenue cutting: } \\
\text { - Decreasing complement size allowed some sites to cover costs of } 4 \text { years } \\
\text { of training. } \\
\text { - Some sites initially decreased their complement size and then grew it } \\
\text { back over time when resources were available. } \\
\text { Revenue generating: } \\
\text { - Fourth-year clinical productivity generated revenue to cover fourth-year } \\
\text { - } \text { salaries. } \\
\text { - Concreasing complement of residents provided more GME funds. } \\
\quad \text { paid for fourth-year costs. }\end{array}$ \\
\hline & $\begin{array}{l}\text { What approaches did } \\
\text { you take to negotiate for } \\
\text { additional resources? }\end{array}$ & $\begin{array}{l}\text { - Residency Program Solutions consultation used to determine if move } \\
\text { to a 4-year model was financially feasible. This approach determined } \\
\text { it was feasible with R4 resident salaries covered by productivity of an } \\
\text { average of four clinics per week and seven patients per clinic, which is } \\
\text { a conservative and achievable productivity for them. } \\
\text { - Developed and presented an accounting of what it would cost to expand. } \\
\text { Didn't need to find additional space for the fourth-year residents. } \\
\text { Currently have rural hospital status, allowing them to only count each } \\
\text { fourth-year resident as one-half slot so they will still remain under } \\
\text { their cap. } \\
\text { External consultant used to assist in generating additional clinical } \\
\text { revenue through better billing and coding to get a higher net revenue } \\
\text { per visit (net gain of } \$ 600 \mathrm{~K} \text { ). This has allowed them to pay for an } \\
\text { additional } 1.0 \text { full-time equivalent faculty salary. }\end{array}$ \\
\hline & $\begin{array}{l}\text { What resources did you } \\
\text { need? }\end{array}$ & $\begin{array}{l}\text { - Fourth-year resident salaries } \\
\text { - One additional faculty and one additional staff position for areas of } \\
\text { concentration (AOCs) and other scheduling. } \\
\text { - Travel costs for AOCs. }\end{array}$ \\
\hline & $\begin{array}{l}\text { What financial advice } \\
\text { would you give to other } \\
\text { residency directors who } \\
\text { are considering offering } 4 \\
\text { years of training? }\end{array}$ & $\begin{array}{l}\text { - Seek outside partnerships (eg, health systems). } \\
\text { - Improve your financial literacy regarding the costs of training. }\end{array}$ \\
\hline \multirow{4}{*}{$\begin{array}{l}4 \text { years of } \\
\text { training optional }\end{array}$} & $\begin{array}{l}\text { What was your approach } \\
\text { for financing the fourth } \\
\text { year? }\end{array}$ & $\begin{array}{l}\text { - Because only a few residents chose to do an additional year, it did not } \\
\text { add significant costs to the residency. }\end{array}$ \\
\hline & $\begin{array}{l}\text { What approaches did } \\
\text { you take to negotiate for } \\
\text { additional resources? }\end{array}$ & $\begin{array}{l}\text { - Not really needed. } \\
\text { - Having to limit the number of PGY1s to keep more PGY4s is a } \\
\text { balancing act. }\end{array}$ \\
\hline & $\begin{array}{l}\text { What resources did you } \\
\text { need? }\end{array}$ & $\begin{array}{l}\text { - Only specific cost was MPH/MBA tuition. } \\
\text { - Needed to negotiate with the University to give them a waiver to } \\
\text { consider residents as employees to be eligible for the substantial } \\
\text { employee tuition break. } \\
\text { - Will need clinical space in the future. }\end{array}$ \\
\hline & $\begin{array}{l}\text { What financial advice } \\
\text { would you give to other } \\
\text { residency directors who } \\
\text { are considering offering } 4 \\
\text { years of training? }\end{array}$ & $\begin{array}{l}\text { - Do what you can with internal funds that are easier to access. } \\
\text { - Play to your strengths to get local resources. }\end{array}$ \\
\hline
\end{tabular}


can support the additional patient care volume provided by the fourthyear residents in their respective family medicine centers.

For many clinics, adding volume or increasing access should add significantly to the bottom line, unless seeing patients results in revenue loss because of payment models. In at least one case, this work had the unanticipated benefit of improving billing and coding practices to further stabilize their economic picture, while also providing a higher salary for fourth-year residents. We learned that fourth-year residents' salaries varied greatly, especially toward the end of the measurement period and in all cases were higher than the average family medicine resident salary of $\$ 57,400$ reported for $2019 .{ }^{28}$ Although productivity may be higher, some level of supervision is still likely to be needed in the fourth year. Notably, many programs lacked a sophisticated understanding of how their residencies are funded, due in part to the lack of transparency with sponsoring institutions that is well recognized in existing literature..$^{29}$ Determining residency funding was essential in determining the feasibility of adding another year of training, which resulted in building a skill set that could benefit many residencies in the discipline.

We also learned that $4 \mathrm{YR}$ residents were statistically more likely to moonlight in their fourth year of training compared to their $3 \mathrm{YR}$ counterparts, though the reasons for moonlighting did not differ and were most commonly reported to gain experience. One possibility is that the intensity of training in the third and fourth year may be less, allowing for more time to moonlight. The debt load between the two groups also did not differ, suggesting this was not a reason for choosing 3 versus 4 years of training. Managing debt load is an important concern for most residents. We found that over one-third of residents in the LoTP were enrolled in loan repayment or scholarship programs with no differences between $3 \mathrm{YR}$ or $4 \mathrm{YR}$ programs. The most recent national survey of 2015 graduates of family medicine programs, as assessed 3 years after graduation, shows that $46 \%$ are enrolled in scholarship or loan repayment programs, an increase from $34 \%$ for 2013 graduates..$^{30}$ Our results are based on resident responses at the start of residency and the higher rates noted nationally are likely due to graduates enrolling in federal, state, or local loan repayment programs after leaving residency.

Though fourth-year residents perceived that the additional year of training would yield higher salaries after graduation, we did not find this to be the case in our assessment of their pretax annual income derived from the graduate survey. Because we collected data on salaries after just 1 year of independent clinical practice, this may not be an accurate picture given that clinical productivity and other aspects of their training will likely result in higher salaries in the next few years, however both 3YR and 4YR programs are equally affected by this limitation. Regional differences could also be an influence on salaries; however, we matched each $4 \mathrm{YR}$ program with a comparable $3 \mathrm{YR}$ program in their region, which should take this into account, as we know the majority of family medicine residency training graduates practice within 100 miles of their training program. ${ }^{31}$

Other residents-some in $4 \mathrm{YR}$ programs and some in 3YR programs-commented on lost income due to delaying entry into independent practice as a financial consideration, with one resident estimating the loss to be about $\$ 200,000$. Other residents preferred not to think about the lost income, suggesting that it is indeed a stressor. Several residents in 4YR programs commented on benefits of additional training that were not finance related, such as gaining additional skills and confidence. Philosophical issues about finances were also a common theme for residents in 4YR programs, who indicated that if money mattered to them, they would have chosen a higher paying discipline. Several of these residents thought that using a financial justification for not moving to 4 years of training was the wrong argument to make, indicating the benefits of additional training outweighed the price tag associated with it. The Medscape Physician Compensation Report for $2019^{32}$ indicates that family physicians' average annual income was $\$ 231,000$ this year, with only pediatrics $(\$ 225,000)$ and public health and preventive medicine $(\$ 209,000)$ being lower. Family considerations were also mentioned as more important than finances in decisions about undertaking an additional year of training.

We found it interesting that many of the residents in $3 \mathrm{YR}$ programs identified nonfinancial concerns regarding a fourth year of training, such as concerns about burnout and that a fourth year of training was perceived as unnecessary or that it was unclear what added benefit would occur from the extra training. This is not to say that loan repayment delay was not a concern. It was certainly an emergent theme, as it was for residents in 4YR programs. As mentioned earlier, high debt load is correlated with significant health and professional consequences. ${ }^{19}$

Length of residency training ranges widely across disciplines from 3 to 8 years, and tends to be longer for the surgical specialties..$^{33,34}$ Residents who undertake internal medicine or pediatrics residencies complete initial training in 3 years, but approximately $75 \%-80 \%$ of internists and $33 \%$ of pediatricians go on to subspecialty training. ${ }^{35,36}$ Emergency medicine (EM) is one of the few specialties with two ACGME-approved training formats with the 36-month format (PGY 1-3) being used by 77\% of residency programs and the 48-month format (PGY 1-4) is used by $23 \%{ }^{37} \mathrm{~A}$ concern about lengthening training in family medicine is the effect it has on the physician workforce, as additional training would decrease the total number of residency graduates 
each year nationally if programs choose to keep their program size the same but spread their positions over 4 years instead of 3 . This is a topic that will surely receive more attention as the discipline moves toward deciding about its future, though allowing both $3 \mathrm{YR}$ and $4 \mathrm{YR}$ programs may be desirable as occurs in emergency medicine.

The strengths of this study include the detailed information collected from programs and residents in both $3 \mathrm{YR}$ and $4 \mathrm{YR}$ programs on financial considerations related to length of training. Participating programs were located in many regions of the United States and matching characteristics were strong. Limitations included the challenge of calculating actual costs of adding a year of training because program directors really do not know how their programs are funded via federal direct and indirect costs, though we did determine what was needed categorically (eg, staff and faculty FTE). This limited our ability to assess detailed costs regarding space and other factors when adding a fourth year of training. This is unsurprising because many published studies have revealed the lack of transparency and accountability in this regard, ${ }^{21,}$ ${ }^{22}$ with one survey study with a $72 \%$ response rate of residency program directors reporting that $59.3 \%$ of directors have attempted to discover this information and fewer than half were successful. ${ }^{22}$

Generalizability of our findings is limited given the small number of programs (13) enrolled in the LoTP and the relatively small sample of $4 \mathrm{YR}$ program graduates, as the 4-year model was not fully implemented in all programs during the entire study period. This is a pilot study by design and such limitations are inherent in studies not statistically powered to achieve certain findings. The representation of female residents in both 3- and 4-year programs was higher than male and higher than the national average of $54.2 \%{ }^{38}$ It is difficult to determine what effect this difference in female representation may have on our findings. We did observe that information on debt load was missing for $14.1 \%$ of $4 \mathrm{YR}$ participants and $9.2 \%$ was missing for 3YR participants, though we were able to capture $85.9 \%$ and $90.8 \%$ for this variable, respectively.

In conclusion, we found that adding a fourth year of training was financially feasible and that the financial impact was greatest for programs that had a required rather than optional fourth year. Strategies used to support the residents' salaries and other costs varied, and consultations with external advisors did help with financial planning. While not a driving factor in their residency selection, concerns about debt load exist among residents, regardless of length of training.

FINANCIAL SUPPORT: The Length of Training Pilot is sponsored by the Accreditation Council for Graduate Medical Education and is funded by the American Board of Family Medicine Foundation. None of the authors have a conflict of interest to declare regarding this article.

CORRESPONDING AUTHOR: Address correspondence to Dr Patricia A. Carney, Professor of Family Medicine, Oregon Health and Science University, 3181 SW Sam Jackson Park Rd. MC: FM, Portland, OR 97239. 503-4949049. carneyp@ohsu.edu.

\section{References}

1. Fields KB. More on the 4-year FM residency program. Fam Med. 2005;37(1):8.

2. Scherger JE. Residencies: heal thyself before extending. Fam Med. 2006;38(3):158-159.

3. Sairenji T, Dai M, Eden AR, Peterson LE Mainous AG III. Fellowship or further training for family medicine residents. Fam Med. 2017;49(8):618-621.

4. Carek PJ. The length of training pilot: does anyone really know what time it takes? Fam Med. 2013;45(3):171-172.

5. Orientale E Jr. Length of training debate in family medicine: idealism versus realism? J Grad Med Educ. 2013;5(2):192-194. doi:10.4300/JGME-D-12-00250.1

6. Saultz JW, David AK. Is it time for a 4-year family medicine residency? Fam Med. 2004;36(5):363-366

7. Schwenk TL. Residency should be expanded to 4 years. Fam Med. 2004;36(9):614-615.

8. Duane M, Phillips RL Jr. Four-year residency training for the next generation of family physicians. Virtual Mentor. 2005;7(6):446-448.

9. Kozakowski S, Abercrombie S, Carek P, et al. Perceived impact of proposed institute of medicine duty hours on family medicine residency programs. Ann Fam Med. 2009;7(3):276-277. doi:10.1370/afm.1007
10. Antiel RM, Thompson SM, Reed DA, et al. ACGME duty-hour recommendations - a national survey of residency program directors. N Engl J Med. 2010;363(8):e12. doi:10.1056/ NEJMp1008305

11. Harris JD, Staheli G, LeClere L, Andersone D, McCormick F. What effects have resident workhour changes had on education, quality of life, and safety? A systematic review. Clin Orthop Relat Res. 2015;473(5):1600-1608. doi:10.1007/ s11999-014-3968-0

12. Walling A, Merando A. The fourth year of medical education: a literature review. Acad Med. 2010;85(11):1698-1704. doi:10.1097/ ACM.0b013e3181f52dc6

13. Stevens CD. Commentary: Taking back Year 4: a call to action. Acad Med. 2010;85(11):16631664. doi:10.1097/ACM.0b013e3181f53487

14. Sklar DP. Making the fourth year more meaningful. Acad Med. 2014;89(4):527-528. doi:10.1097/ACM.0000000000000184

15. Bohmer RM. Managing the new primary care: the new skills that will be needed. Health Aff (Millwood). 2010;29(5):1010-1014. doi:10.1377/ hlthaff.2010.0197

16. Pugno PA. One giant leap for family medicine: preparing the 21 st-century physician to practice patient-centered, high-performance family medicine. J Am Board Fam Med. 2010;23(suppl 1):S23-S27. doi:10.3122/jabfm.2010.S1.090291

17. Congressional Research Service. Federal Support for Graduate Medical Education: An Overview. December 27th, 2018: https://fas.org/sgp/ crs/misc/R44376.pdf. Accessed January 7, 2020.

18. Wisenberg BD. Taking the sting out of medical school debt. AAMC News. April 4, 2017. https:// news.aamc.org/medical-education/article/taking-sting-out-medical-school-debt/ Accessed September 16, 2019.

19. Connelly P, List C. The effect of understanding issues of personal finance on the well-being of physicians in training. WMJ. 2018;117(4):164166.

20. Phillips J. The impact of debt on young family physicians: unanswered questions with critical implications. J Am Board Fam Med. 2016;29(2):177-179. doi:10.3122/jabfm.2016.02.160034

21. Chaudhry SI, Khanijo S, Halvorsen AJ, McDonald FS, Patel K. Accountability and transparency in graduate medical education expenditures. Am J Med. 2012;125(5):517-522. doi:10.1016/j. amjmed.2012.01.007

22. Committee on the Governance and Financing of Graduate Medical Education; Board on Health Care Services; Institute of Medicine. Graduate Medical Education That Meets the Nation's Health Needs. Eden J, Berwick D, Wilensky G, eds. Washington (DC): National Academies Press (US); 2014 Sep 30.

23. Length of Training Pilot Project. http://www. lotpilot.org. Accessed August 12, 2019.

24. Johnson B, Christensen LB. Educational research: quantitative, qualitative, and mixed approaches. 4th ed. Thousand Oaks, CA: SAGE Publications; 2012.

25. Creswell JW. Qualitative inquiry and research design: choosing among five approaches. 2nd ed. Thousand Oaks, CA: Sage Publications; 2007. 
26. Accreditation Council for Graduate Medical Education. Specialty-specific references for DIOs: number of faculty members 6/2018. https://www.acgme.org/Portals/0/PDFs/Specialty-specific\%20Requirement\%20Topics/DIONumber_of_Faculty.pdf. Accessed February 18 2020 .

27. Accreditation Council for Graduate Medical Education. Accreditation Data System (ADS). https://www.acgme.org/Data-Collection-Systems/Overview. Accessed March 18, 2020.

28. Medscape Residents Salary and Debt Report 2019: https://www.medscape.com/ slideshow/2019-residents-salary-debt-report-6011735\#3. Accessed March 13, 2020.

29. Regenstein M, Snyder JE, Jewers MM, Nocella $\mathrm{K}$, Mullan F. Comprehensive revenue and expense data collection methodology for teaching health centers: a model for accountable graduate medical education financing. J Grad Med Educ. 2018;10(2):157-164 doi:10.4300/ JGME-D-17-00542.1

30. Association of Family Medicine Resideny Directors. 2018 National Family Medicine Residency Graduate Survey. https://www.afmrd.org/page/ national-family-medicine-graduate-survey. Accessed Feb 12, 2020
31. Fagan EB, Gibbons C, Finnegan SC, et al. Family medicine graduate proximity to their site of training: policy options for improving the distribution of primary care access. Fam Med 2015;47(2):124-130.

32. Medscape Physician Compensation Report 2019: https://www.medscape.com/ slideshow/2019-compensation-overview-6011286\#3. Accessed December 19, 2019.

33. Accreditation Council for Graduate Medical Education. AMA Green Books. https://www. acome.org/About-Us/Publications-and-Resources/AMA-Green-Books. Accessed February 18, 2020.

34. American Medical Association. FREIDA https://freida.ama-assn.org/. Accessed Febraury 18, 2020.

35. Byrne BJ, Katakam SK, Frintner MP, Cull WL. Early career experiences of pediatricians pursuing or not pursuing fellowship training. Pediatrics. 2015;136(4):672-679. doi:10.1542/ peds.2014-3973

36. Henderson D. Most internal medicine residents plan subspecialty careers. Medscape, December 4th, 2012: https://www.medscape. com/viewarticle/775601 (Accessed 02/19/20).
37. Smith-Coggins R, Baren JM, Beeson MS, et al; Research Committee, American Board of Emergency Medicine. American Board of Emergency Medicine report on residency training information (2013-2014), American Board of Emergency Medicine. Ann Emerg Med. 2014;63(5):637-645. doi:10.1016/j.annemergmed.2014.03.008

38. American Academy of Family Physicians. Selected Demographic Characteristics of AAFP Members (as of December 31, 2018). https:// www.aafp.org/about/the-aafp/family-medicinespecialty/facts/table-2.html Accessed February $12,2020$. 